\title{
Oligoarticular Tuberculous Infection of the Knee and Acromioclavicular Joints: An Unusual Manifestation and Characteristic Magnetic Resonance Imaging Findings
}

\author{
Diz ve Akromiyoklaviküler Eklemlerin Oligoartiküler Tüberküloz Enfeksiyonu: \\ Nadir Bir Görünüm ve Karakteristik Manyetik Rezonans Görüntüleme Bulguları
}

\author{
Remzi ÇEVİK, ${ }^{1}$ Yaşar BÜKTE, ${ }^{2}$ Kemal NAS, ${ }^{1}$ Figen CEYLAN ÇEVİK, ${ }^{1}$ Gökhan KIRBAŞ, ${ }^{3}$ Hüseyin BÜYÜKBAYRAM ${ }^{4}$ \\ Departments of ${ }^{1}$ Physical Medicine and Rehabilitation, ${ }^{2}$ Radiology, ${ }^{3}$ Pulmonary Disease, ${ }^{4}$ Pathology, \\ Medical Faculty of Dicle University, Diyarbakır, Turkey
}

An increased incidence of tuberculosis has been seen in recent years due to factors such as immunocompromising diseases and drug use. There has also been an increase in osteoarticular involvement. In this article, we report a 22-yearold male patient who was diagnosed with tuberculosis of the knee and acromioclavicular joints. Tuberculosis of this joint is very rare, and concomitancy with the knee has not been reported in the literature. The definitive diagnosis was performed by the histopathological examination of a synovial biopsy. The chest radiograph showed cavitation and the magnetic resonance imaging examination showed characteristic demonstrative findings. Antituberculosis drug treatment was started with a satisfactory response.

Key words: Acromioclavicular joint; knee; MRI; osteoarticular tuberculosis.

According to the World Health Organization (WHO) report in 2009, the total number of incident cases of tuberculosis ( $\mathrm{Tbc}$ ) has been increasing, although in absolute terms the number of cases per capita has been falling as a result of population growth. However, the rate of decline is slow at less than $1 \%$ per year. ${ }^{[1]}$ In addition, the incidence of $\mathrm{Tbc}$ remains high in both developing and developed countries. This is largely due to the acquired immune deficiency syndrome (AIDS) epidemic and other immunosuppressive factors,
Son yıllarda immün yetersizlik oluşturan hastalıklar ve ilaç kullanımı gibi nedenlerle tüberküloz insidansında artış görülmektedir. Ayrıca osteoartiküler tutulum da artmıştır. Bu yazıda diz ve akromiyoklaviküler eklem tüberkülozu tanısı konulan 22 yaşında bir erkek hasta sunuldu. Bu eklemin tüberkülozu çok nadirdir ve diz eklem tutulumu ile birlikteliği literatürde bildirilmemiştir. Kesin tanı sinoviyal biyopsinin histopatolojik incelemesiyle konuldu. Göğüs radyografisinde kavitasyon ve manyetik rezonans görüntüleme incelemesinde ise ile karakteristik demonstratif bulgular saptandı. Antitüberküloz ilaç tedavisine tatmin edici bir yanıt ile başlandı.

Anahtar sözcükler: Akromiyoklaviküler eklem; diz; MRG; osteoartiküler tüberküloz.

immigration, homelessness and a decline in Tbc control programs. ${ }^{[2,3]}$ The introduction of anti-tumor necrosis factor alpha (anti-TNF- $\alpha$ ) drugs has rekindled interest in $\mathrm{Tbc}$ encountered in rheumatology. ${ }^{[4]}$

Skeletal Tbc occurs in 1\%-3\% of cases and represents a third form of extra pulmonary Tbc after ganglion and kidney involvement. ${ }^{[5]}$ Although Tbc can involve any area of the musculoskeletal system, the majority of the $\mathrm{Tbc}$ arthritis cases ( 85\%) present with chronic monoarthritis involving large and medium

\footnotetext{
Received: April 28, 2009 Accepted: June 29, 2009

Correspondence: Remzi Çevik, M.D. Dicle Üniversitesi Tıp Fakültesi, Fiziksel Tıp ve Rehabilitasyon Anabilim Dalı, 21280 Diyarbakır, Turkey.

Tel: +90 412 - 2488001 e-mail: ftremzi@hotmail.com

Presented at the $3^{\text {rd }}$ National Congress of Rheumatic Diseases, May 14-18, 2008, Antalya, Turkey.

C2011 Turkish League Against Rheumatism. All rights reserved.
} 
weight-bearing joints with the hip and knee being the most common sites. ${ }^{[6]}$ Acromioclavicular joint involvement is very rare in Tbc arthritis. When a patient affected with chronic arthritis presents with insidious evolution and risk factors, it is very important to consider a Tbc etiology.

The aim of this case presentation is to describe the uncommon concomitant knee and acromioclavicular joint involvement in $\mathrm{Tbc}$, characteristic magnetic resonance imaging (MRI) findings that could be shown in osteoarticular involvement, and the diagnostic problems that may arise and lead to a delay in treatment.

\section{CASE REPORT}

A 22-year-old man presented with an eight month history of shoulder and knee pain along with swelling. He was a university student. Eight months previously he experienced right shoulder and knee pain with swelling but no redness. He visited an outpatient clinic and was prescribed analgesic anti-inflammatory drugs. This treatment eliminated the shoulder and knee pain but did nothing to stop the swelling of those joints. He also complained of cough and sputum and reported a history of Tbc in his cousin.

During a systemic examination he had swelling but no pain in the right acromioclavicular joint. He had swelling, pain and movement limitation in the right knee. The knee swelling was semisolid and involved a superior tibiofibular articulation that had the characteristics of a mobile mass.

Laboratory blood tests revealed an $8.65 \times 109 / \mathrm{L}$ serum leukocyte count, $31 \mathrm{~mm} /$ hour erythrocyte sedimentation rate, and $64.7 \mathrm{mg} / \mathrm{l}$ serum reactive protein. A knee puncture was performed, and the synovial fluid analysis showed an increased protein level with an intensive accumulation of lymphocytes. Ziehl-Nielsen, gram stains, aerobic and anaerobic cultures, and deoxyribonucleic acid (DNA) testing for Mycobacterium tuberculosis (amplified using the polymerase chain reaction; PCR) were negative. Throat and sputum cultures were also negative.

Consolidation and irregular cavitation in the upper zone of the left lung was detected in the chest radiograph (Figure 1); however, knee radiographs were considered normal. Magnetic resonance imaging of the right knee revealed inflammation in the knee, around the joint and in the superior tibiofibular articulation. The knee MRI also revealed centrally necrotic abscesses with peripheral enhancement of the rim after a gadolinium injection (Figure 2). An MRI of the right shoulder also showed increased inflammatory signal changes in the acromioclavicular joint and adjacent soft tissue with enhancement after gadolinium injection (Figure 3). The purified protein derivative (PPD) skin test for Tbc measured $22 \mathrm{~mm}$. A synovial biopsy taken from the knee detected granulomatous inflammation with caseation necrosis. Antibiotic treatment with isoniazid, rifampicin, ethambutol and pyrazinamide were prescribed for two months followed by rifampicin and isoniazid for seven months. The patient showed significant improvement in the knee and shoulder within two months and close to complete improvement within six months.

\section{DISCUSSION}

Increased incidence of osteoarticular $\mathrm{Tbc}$ has been observed in recent years due to many factors including human immunodeficiency virus (HIV) infection, immigration from endemic areas, alcoholism, chronic kidney disorders, immunosuppressive therapy, homelessness, crowded living conditions, drug addiction, intra-articular steroid injection, systemic illness and poor access to medical care. ${ }^{[7]}$ Tuberculosis is generally classified as pulmonary and extrapulmonary. Approximately $10-11 \%$ of extrapulmonary Tbc involves bone and joints (representing 1-3\% of all cases of $\mathrm{Tbc}$ infection). Of these, $50 \%$ were associated with pulmonary Tbc. ${ }^{[6,10]}$

The diagnosis of bone and joint Tbc is a clinical challenge due to its insidious onset, slow progression, difficulty of laboratory diagnosis and the occasional absence of extra-articular features. Spinal Tbc is the

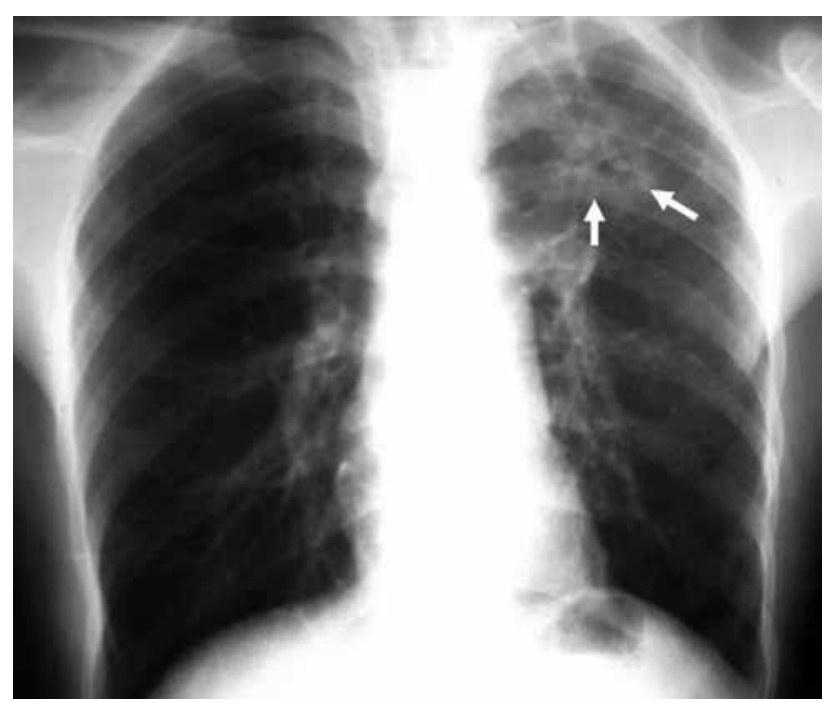

Figure 1. Consolidation and irregular cavitation in the upper zone of the left lung (arrows). 

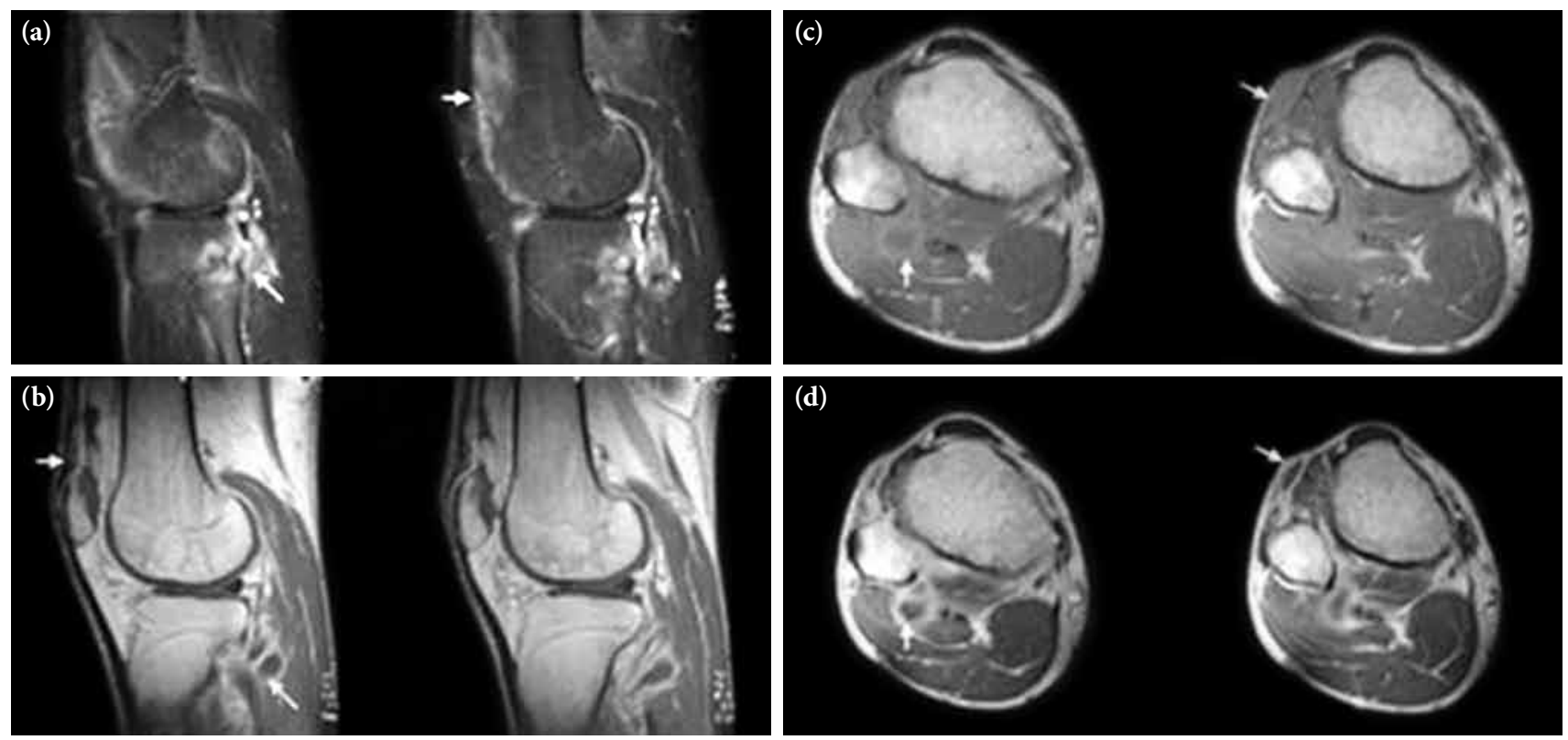

Figure 2. Magnetic resonance imaging of the right knee. (a) Fat-saturated sagittal T2-weighted images show high signal intensity changes of knee joint surrounding soft tissue, bone marrow, synovium and adjacent tibiofibular articulation. (b) Gadoliniumenhanced sagittal T1-weighted magnetic resonance images show pyogenic abscesses (arrows) to surrounding soft tissues of the knee joint with a thick irregularly enhanced rim. (c, d) T1-weighted axial images. (c) Centrally low hypointense inflammatory signal changes in anterolateral subcutaneous and posterior soft tissue of the bone and (d) after gadolinium injection peripherally enhanced abscesses are seen (arrows).

most common form of osteoarticular Tbc followed by the hip and knee. In spite of rare cases of direct inoculation, osteoarticular $\mathrm{Tbc}$ is caused by haematogenous, lymphatic or direct local spread of tubercle bacilli from other lesions, from a quiescent pulmonary primary or other extraosseous foci. ${ }^{[11,12]}$ In the present case, tubercle bacilli may have been spread by haematogenous or lymphatic means from one joint to the other as the involved joints were far from each other.
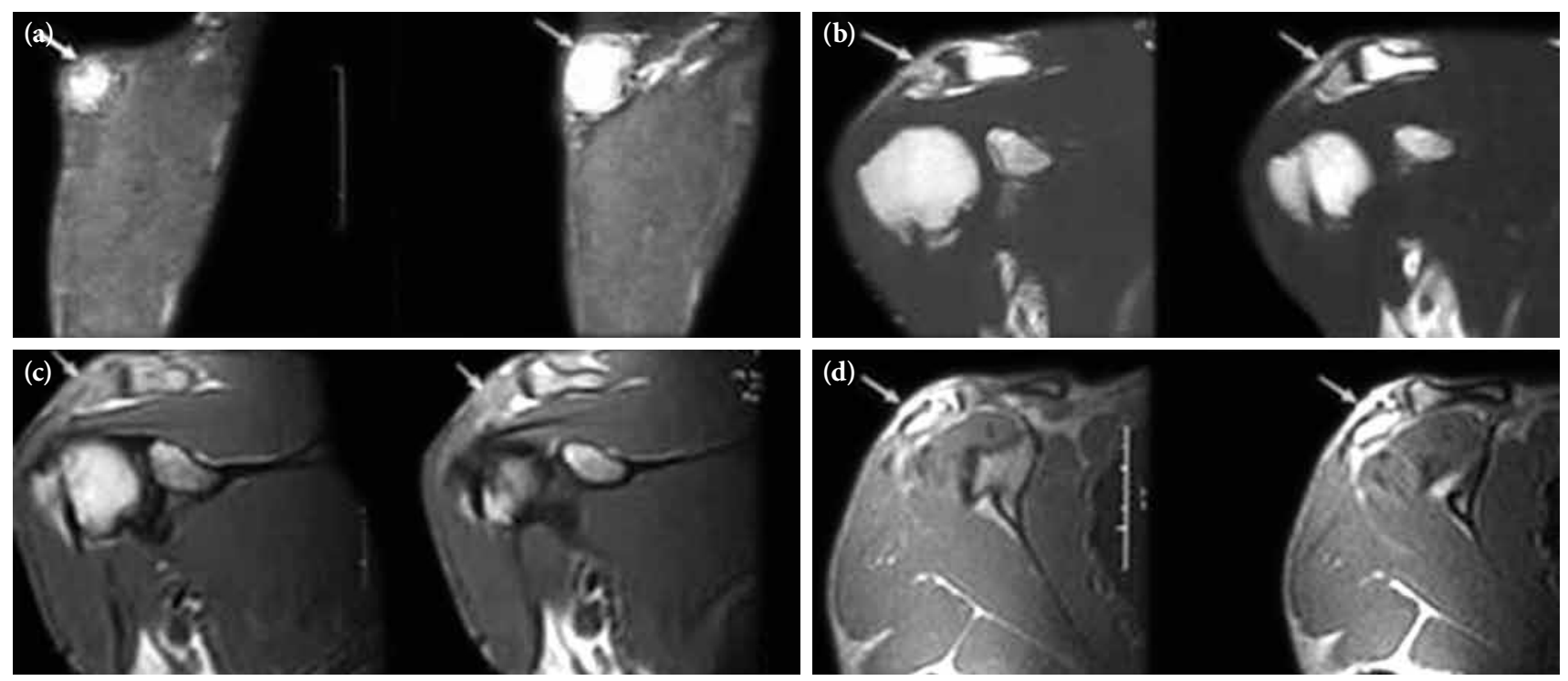

Figure 3. Magnetic resonance imaging of the right shoulder. (a) Fat-saturated coronal T2-weighted images show hyperintens signal changes in subcutaneous tissue of anterolateral right shoulder (arrows). (b) T2-weighted coronal images show hyperintensity in acromioclavicular joint extended to adjacent subcutaneous soft tissue (arrows). (c, d) T1-weighted coronal images. (c) Heterogeneous signal changes in acromioclavicular joint extended to soft and cutaneous tissues and (d) after gadolinium injection marked enhancement are seen (arrows). 
Tuberculous arthritis is characteristically monoarticular and rarely involves more than one joint. ${ }^{[13,14]}$ Furthermore, acromioclavicular joint involvement is very infrequent in Tbc arthritis. In this case we report both unusual presentations of Tbc arthritis: a rare location and the simultaneous inflammation of two joints.

Tuberculous arthritis commonly presents with chronic pain accompanied by swelling and progressive loss of function. The onset is usually insidious, the diagnosis often delayed, and functional results may be poor after treatment, especially when there is extensive bone and articular destruction. Furthermore, a history of Tbc infection or exposure may not be present and no radiographic evidence of pulmonary involvement can be identified in approximately $50 \%$ of patients. A negative tuberculin skin test does not exclude diagnosis, as is the case with immunocompromised patients. Radiological findings are nonspecific in early stages. As the disease progresses, periarticular osteoporosis, peripherally located osseous erosions and gradual narrowing of the cartilage space are seen as typical radiographic findings. ${ }^{[7,11,15]}$ In this case, we detected articular and soft tissue changes which continued until specific antituberculous treatment was administered.

Magnetic resonance imaging is the best modality to evaluate soft tissue affection by demonstrating marrow changes, joint effusion, synovitis, pannus, and cartilage and bone erosions. ${ }^{[2,16]}$ Joint and periarticular involvement and lesions are particularly well defined by an MRI. The definitive diagnosis is performed from a positive mycobacterial culture and a histological examination of synovial fluid or synovial membranes. An examination of a biopsy specimen is an important and useful diagnostic method. Amplifying DNA of Mycobacterium tuberculosis from synovial fluid or bone by PCR could be useful for the early diagnosis of Tbc. We performed a definitive diagnosis through the histopathological examination of a synovial biopsy, a chest radiograph showing cavitation and the definitive demonstration on MRI examination. This was done in spite of the lack of positivity of mycobacterial culture and PCR. In addition, following the initiation of specific antituberculous treatment, the patient showed significant improvement in the knee and shoulder within two months with close to complete improvement within six months. We extended treatment to nine months in accordance with the recommendations for musculoskeletal tuberculosis in the literature and by the Turkey Ministry of Health. ${ }^{[17,18]}$
In conclusion, acromioclavicular joint involvement is very rare in $\mathrm{Tbc}$ arthritis. The simultaneous involvement of knee and acromioclavicular joints has not been reported in the literature. Mycobacterium tuberculosis was not detected from sputum, throat or synovial specimens. A definitive diagnosis was secured by histological examination of a synovial biopsy. The MRI showed characteristic joint and soft tissue affection. Osteoarticular Tbc should be considered in patients who present with unexplained joint soft tissue swelling and pain, particularly if they are immunocompromised or live in an endemic area.

\section{Declaration of conflicting interests}

The authors declared no conflicts of interest with respect to the authorship and/or publication of this article.

\section{Funding}

The authors received no financial support for the research and/or authorship of this article.

\section{REFERENCES}

1. WHO Report 2009. Global tuberculosis control epidemiology, strategy, financing. Switzerland: World Health Organization; 2009. p. 12.

2. Teo HE, Peh WC. Skeletal tuberculosis in children. Pediatr Radiol 2004;34:853-60.

3. Rasool MN. Osseous manifestations of tuberculosis in children. J Pediatr Orthop 2001;21:749-55.

4. Keane J, Gershon S, Wise RP, Mirabile-Levens E, Kasznica J, Schwieterman WD, et al. Tuberculosis associated with infliximab, a tumor necrosis factor alpha-neutralizing agent. N Engl J Med 2001;345:1098-104.

5. Davidson PT, Horowitz I. Skeletal tuberculosis. A review with patient presentations and discussion. Am J Med 1970;48:77-84.

6. Malaviya AN, Kotwal PP. Arthritis associated with tuberculosis. Best Pract Res Clin Rheumatol 2003; 17:319-43.

7. Domingo A, Nomdedeu M, Tomás X, García S. Elbow tuberculosis: an unusual location and diagnostic problem. Arch Orthop Trauma Surg 2005;125:56-8.

8. Khan K, Muennig P, Behta M, Zivin JG. Global drugresistance patterns and the management of latent tuberculosis infection in immigrants to the United States. N Engl J Med 2002;347:1850-9.

9. Vallès X, Sánchez F, Pañella H, García De Olalla P, Jansà JM, Caylà JA. Imported tuberculosis: an emerging disease in industrialised countries. Med Clin (Barc) 2002;118:3768. [Abstract]

10. Harrington JT. Mycobacterial and fungal infections. In: Ruddy S, Harris ED, Sledge CB, Budd CR, Sergent JS, editor. Kelley's textbook of rheumatology. 6th ed. Philadelphia: W.B. Saunders Company; 2001. p. 1493-505. 
11. Esteban PL, Soriano A, Tomás X, Quintana L, GarcíaRamiro S. Tuberculous osteomyelitis of the knee: a case report. Arch Orthop Trauma Surg 2006;126:631-3.

12. Muradali D, Gold WL, Vellend H, Becker E. Multifocal osteoarticular tuberculosis: report of four cases and review of management. Clin Infect Dis 1993;17:204-9.

13. Cachafeiro-Vilar A, García-Padilla C, Reyes E, Hernández-Molina G. Polyarticular arthritis secondary to Mycobacterium bovis infection: an unusual clinical presentation. Joint Bone Spine 2007;74:107-9.

14. Linares LF, Valcarcel A, Mesa Del Castillo J, Saiz E, Bermudez A, Castellon P. Tuberculous arthritis with multiple joint involvement. J Rheumatol 1991;18:635-6.
15. Martini M. Tuberculosis of the bones and joints. 2nd ed. New York: Springer Berlin Heidelberg; 1988.

16. Sawlani V, Chandra T, Mishra RN, Aggarwal A, Jain UK, Gujral RB. MRI features of tuberculosis of peripheral joints. Clin Radiol 2003;58:755-62.

17. Marquez J, Espinoza LR. Mycobacterial, brucella, fungal and parasitic arthritis. In: Hochberg MC, Silman AJ, Smolen JS, Weinblatt ME, Weisman MH, editors. Rheumatology. 4th ed. Philadelphia: Mosby Elsevier; 2008. p. 1029-38.

18. Özkara Ş, Aktaş Z, Özkan S, Ecevit H. Türkiye'de tüberkülozun kontrolü için başvuru kitabı. Ankara: Rekmay; 2003. s. 26. 